University of Nebraska - Lincoln

DigitalCommons@University of Nebraska - Lincoln

1998

\title{
Atrazine, Deethylatrazine, and Deisopropylatrazine Persistence Measured in Groundwater in Situ under Low-Oxygen Conditions
}

Sharon Papiernik

University of Nebraska-Lincoln

Roy Spalding

University of Nebraska-Lincoln

Follow this and additional works at: https://digitalcommons.unl.edu/usdaarsfacpub

Part of the Agricultural Science Commons

Papiernik, Sharon and Spalding, Roy, "Atrazine, Deethylatrazine, and Deisopropylatrazine Persistence Measured in Groundwater in Situ under Low-Oxygen Conditions" (1998). Publications from USDA-ARS / UNL Faculty. 252.

https://digitalcommons.unl.edu/usdaarsfacpub/252

This Article is brought to you for free and open access by the U.S. Department of Agriculture: Agricultural Research Service, Lincoln, Nebraska at DigitalCommons@University of Nebraska - Lincoln. It has been accepted for inclusion in Publications from USDA-ARS / UNL Faculty by an authorized administrator of DigitalCommons@University of Nebraska - Lincoln. 


\title{
Atrazine, Deethylatrazine, and Deisopropylatrazine Persistence Measured in Groundwater in Situ under Low-Oxygen Conditions
}

\author{
Sharon K. Papiernik* and Roy F. Spalding \\ University of Nebraska Water Sciences Laboratory, Lincoln, Nebraska 68583-0844
}

\begin{abstract}
The degradation of atrazine [2-chl oro-4-(ethylamino)-6-isopropylamino-1,3,5-triazine], deethylatrazine [DEA; 2-amino-4-chloro-6-(isopropylamino)-1,3,5-triazine], and deisopropylatrazine [DIA; 2-amino-4-chloro-6-(ethylamino)-1,3,5-triazine] was assessed under limited oxygen conditions using in situ microcosms. Denitrification was induced in a shallow sand and gravel aquifer to measure the potential for degradation of atrazine, DEA, and DIA under low- $\mathrm{O}_{2}$ conditions. The dissolved oxygen content decreased from $7-8 \mathrm{mg} / \mathrm{L}$ to $\leq 1 \mathrm{mg} / \mathrm{L}$ within 4 days and remained $\leqslant 3 \mathrm{mg} / \mathrm{L}$ for the remainder of the 45-day experiment. Atrazine, DEA, and DIA concentrations (normalized to the bromide concentration at each sampling time to account for dilution) did not show a significant decrease with time, indicating that these compounds are relatively stable under the low- $\mathrm{O}_{2}$ conditions induced in the aquifer. Although removal of one alkyl group has been proposed as the rate-limiting step in atrazine degradation, no transformation of either monodealkylated metabolite (DEA or DIA) was observed in this study.
\end{abstract}

Keywords: Degradation; triazine; groundwater; denitrification; metabolite

\section{INTRODUCTION}

Atrazine [2-chloro-4-(ethylamino)-6-isopropylamino1,3,5-triazine] and its degradation products are common contaminants of groundwater in agricultural regions of the United States (Kolpin et al., 1996; Ritter, 1990; Spalding et al., 1989). The degradative properties of atrazine have been assessed in both laboratory and field studies. Extensive degradation has been observed in surface soils, with the removal of the alkyl side chains reported as the initial step in the microbial degradation pathway (Behki and Khan, 1986; Giardina et al., 1982; Wolf and Martin, 1975). Others report that the dechlorination of atrazine to form hydroxyatrazine [2-hydroxy4-(ethylamino)-6-(isopropylamino)-1,3,5-triazine] appears to be the ratelimiting step to further degradation (Assaf and Turco, 1994; Chung et al., 1995; Mandelbaum et al., 1993). Formation of hydroxyatrazine may be a biotic process (Mandel baum et al., 1995; Stucki et al., 1995; Yanze-K ontchou and Gschwind, 1994) as well as an abiotic process; formation of deethylatrazine (DEA) and deisopropylatrazine (DIA) may al so be biotic or abiotic (Kruger et al., 1997).

Mineralization of the triazine ring is generally slower and less extensive than dealkylation (MCMahon et al., 1992; Nair and Schnoor, 1992, 1994). Mirgain et al. (1993) isol ated a bacterium that could degrade atrazine and also identified an apparent synergistic relationship between two bacteria that could degrade atrazine together. Several researchers have isolated bacteria or mixed cultures that could use atrazine as the sole carbon source (Behki and Khan, 1986; Giardina et al., 1980; Mandel baum et al., 1993; Yanze-Kontchou and Gschwind, 1994) or that could use atrazine or its

* Address correspondence to this author at the USDA-ARS, U.S. Salinity Laboratory, 450 W. Big Springs Rd., Riverside, CA 92507-4617 [tel ephone (909) 369-4802; fax (909) 342-4964; e-mail spapiernik@ussl.ars.usda.gov]. metabolites as the sole nitrogen source (Alvey and Crowley, 1995; Assaf and Turco, 1994; Giardina et al., 1980; Mandel baum et al., 1995; Radosevich et al., 1995). The addition of a carbon source has been shown to enhance the degradation of several compounds under various conditions. Examples include the accelerated degradation of atrazine metabolites (Assaf and Turco, 1994) and 2,4,5-trichlorophenoxyacetic acid (2,4,5-T) under sulfatereducing or methanogenic conditions (Gibson and Suflita, 1990), atrazine and al achlor [2-chloro2',2'-diethyl-N-(methoxymethyl)acetanilide] under denitrifying conditions (Wilber and Parkin, 1995), and total triazine in atrazine-spiked sediments under anaerobic conditions (Chung et al., 1996).

Some isolated bacteria capable of degrading atrazine have been classified as facultative anaerobes (V essee et al., 1983) that can reduce nitrate (Mandel baum et al., 1995; Radosevich et al., 1995; Yanze-Kontchou and Gschwind, 1994). The degradation of atrazine in surface soils has been reported to be slower under anaerobic conditions than under aerobic conditions (Nair and Schnoor, 1992, 1994; Yanze-Kontchou and Gschwind, 1995). Wilber and Parkin (1995) observed no significant differences in the rate of atrazine degradation by aerobic, nitrate-reducing, sulfate-reducing, or methanogenic microbial cultures. The rate of atrazine degradation has been reported to be slower under lowoxygen conditions than under aerobic conditions in estuarine sediments ( ones et al., 1982) and wetland sediments (Chung et al., 1995; Ro and Chung, 1995). Stucki et al. (1995) reported limited atrazine degradation under low $-\mathrm{O}_{2}$ conditions $(<2 \mathrm{mg} / \mathrm{L})$ but rapid degradation when nitrate was available as an alternative electron acceptor. Differing results have been obtained for atrazine degradation under anaerobic conditions in wetland soils: Chung et al. (1995) observed $\sim 50 \%$ degradation of atrazine (milligrams per liter levels) in 38 weeks under anaerobic conditions in 
slurries of wetland soil and wetland water; Gu et al. (1992) observed no degradation of similar concentrations of atrazine under methanogenic and nitrate-reducing conditions in laboratory microcosms of wetland soil slurries incubated for $\geq 300$ days.

Atrazine degradation rates in groundwater have been estimated by incubating laboratory microcosms containing aquifer material and herbicide solution and monitoring solution concentrations or ${ }^{14} \mathrm{CO}_{2}$ evolution from ${ }^{14} \mathrm{C}$-labeled atrazine with time. No dealkylation of atrazine was observed in 70 days in laboratory studies conducted by inoculating cement-grade sand with aquifer microbes at 13 or $28{ }^{\circ} \mathrm{C}$ (Wehtje et al., 1983). McMahon et al. (1992) observed no mineralization of the triazine ring in 23 days, with some dealkylation to DIA [2-amino-4-chl oro-6-(ethylamino)-1,3,5-triazine] in systems containing shallow aquifer sediments; deeper sediments exhibited less dealkylation. Vanderheyden et al. (1997) observed rapid degradation of atrazine in sediment samples collected from the saturated zone, and the metabolites were unidentified; mineralization of $\left[{ }^{14} \mathrm{C}\right.$ ]atrazine began after a lag phase of $\sim 25$ days and $\sim 25 \%$ of the applied $\left[{ }^{14} \mathrm{C}\right]$ atrazine was mineralized in 75 days. Agertved et al. (1992) observed no decrease in atrazine concentrations during 74 days in laboratory microcosms of groundwater and aquifer material.

The fate of herbicides in groundwater is difficult to assess, since many physical and chemical processes affect concentrations in situ. Some parameters, such as oxygen content, redox potential, and microbial population, are difficult to simultaneously control in the laboratory and may not be representative of aquifer characteristics. The persistence of contaminants in situ can be determined by monitoring groundwater concentrations in field transport studies. Agertved et al. (1992) observed no degradation of high concentrations of atrazine $(\sim 400 \mu \mathrm{g} / \mathrm{L})$ in 96 days in an aerobic aquifer [dissolved oxygen (DO) ranging from 2.1 to $8.0 \mathrm{mg} / \mathrm{L}$ ]. Widmer and Spalding (1995) observed no degradation at concentrations more typical of nonpoint source contamination [atrazine, DEA [2-amino-4-chl oro-6-(i sopropylamino)-1,3,5-triazine], and DIA, each at $\sim 3 \mu \mathrm{g} / \mathrm{L}]$ in 3 months in an aerobic aquifer (DO $\approx 6.9 \mathrm{mg} / \mathrm{L}$ ).

A method to measure the rate of transformation of contaminants in situ was presented by Gillham et al. (1990), who followed the rate of denitrification and benzene degradation using an in situ microcosm (ISM). ISMs isolate a portion of the aquifer from horizontal advective flow. They also minimize disturbance of the aquifer and allow for measurement of reaction rates under aquifer conditions, since parameters such as $\mathrm{pH}$, Eh, DO, the composition of the groundwater and solid matrix, and the microbial population remain essentially unchanged (Gillham et al., 1990). Agertved et al. (1992) used microcosms of this design to determine the persistence of $400 \mu \mathrm{g} / \mathrm{L}$ atrazine and MCPP [potassium salt of 2-(2-methyl-4-chlorophenoxy)propionic acid] in an aerobic aquifer; they observed minimal degradation of both compounds in 47 days.

Information regarding the transformation potential of pesticides in groundwater under low-oxygen conditions is lacking. Much of the research on the rate of triazine herbicide degradation in groundwater has been conducted in the laboratory. Field studies have largely been conducted under aerobic conditions (Agertved et al., 1992; Widmer and Spalding, 1995). The objective of this study was to use ISMs to determine the persis-

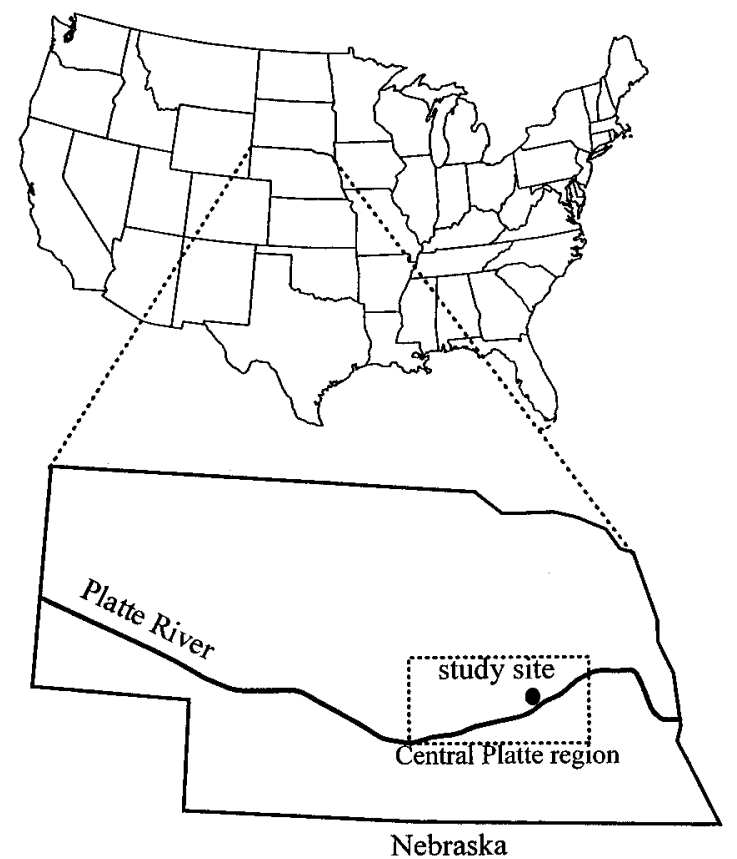

Figure 1. Location of the study site in central Nebraska.

tence of atrazine and two of its deal kylated metabolites, DEA and DIA, under oxygen-limited conditions induced in a shallow sand and gravel aquifer contaminated by both atrazine and nitrate.

\section{EXPERIMENTAL PROCEDURES}

Experimental Site. The 0.2-ha study site was located in Merrick County in the Central Platte region of Nebraska (Figure 1 ) and is surrounded by farmland cropped to irrigated corn. The area has a long history of atrazine application; sandy soils and a shallow water table make the area's groundwater vulnerable to agrichemical contamination. Both atrazine and nitrate are commonly detected in the groundwater of Merrick County (University of Nebraska Water Sciences Laboratory, 1994). Groundwater collected from 18 irrigation wells in Merrick County had atrazine concentrations ranging from $<0.005$ to almost $7 \mu \mathrm{g} / \mathrm{L}$ and nitrate-N concentrations from $\sim 5$ to $31 \mathrm{mg} / \mathrm{L}$ (Spalding et al., 1979). The aquifer is characterized as Pleistocene Age sands and gravels. The water table is at a depth of $2-3 \mathrm{~m}$.

Microcosms (Figure 2) were constructed and installed as described in Bates and Spalding (1998). Holes were excavated to $\sim 2 \mathrm{~m}$, and steel caissons (1.2 $\mathrm{m}$ diameter $\times 2.5 \mathrm{~m}$ long) were installed to keep the holes open. A PVC pipe $(0.25 \mathrm{~m}$ diameter $\times 1.2 \mathrm{~m}$ long) was inserted into the aquifer at the bottom center of each hole. The PVC pipe was voided of sediment so that the microcosms could be installed well bel ow the water table. Microcosms (16 cm diameter $\times 61 \mathrm{~cm}$ long) were vibrated to a depth of $\sim 3 \mathrm{~m}$ below land surface with a vibracorer. Replicate ISMs were spaced at $\sim 4.6 \mathrm{~m}$ intervals. Each mi crocosm has a volume of $\sim 11 \mathrm{~L}$ when empty; when in place in the aquifer (filled with sediment), they each contain $\sim 3.7 \mathrm{~L}$ of pore water. Each ISM is open at the bottom to allow exchange with the aquifer water. The top is sealed with a threaded stainless steel cap. A main screen (Figure 2) was used for the injection or withdrawal of large volumes of water. The ISMs also contained a miniature drive-point (Figure 2), which was used to collect water samples to monitor the processes occurring within the ISM.

Injection and Monitoring of Solutes. At least 3 volumes of stagnant water $(\sim 30 \mathrm{~L})$ were removed from duplicate microcosms and discarded. For the injection of solutes, $\sim 10$ $\mathrm{L}$ of water contained within the microcosm was vacuumpumped into a glass flask without exposure to the atmosphere. Solutes were injected into the glass flask through a septum 


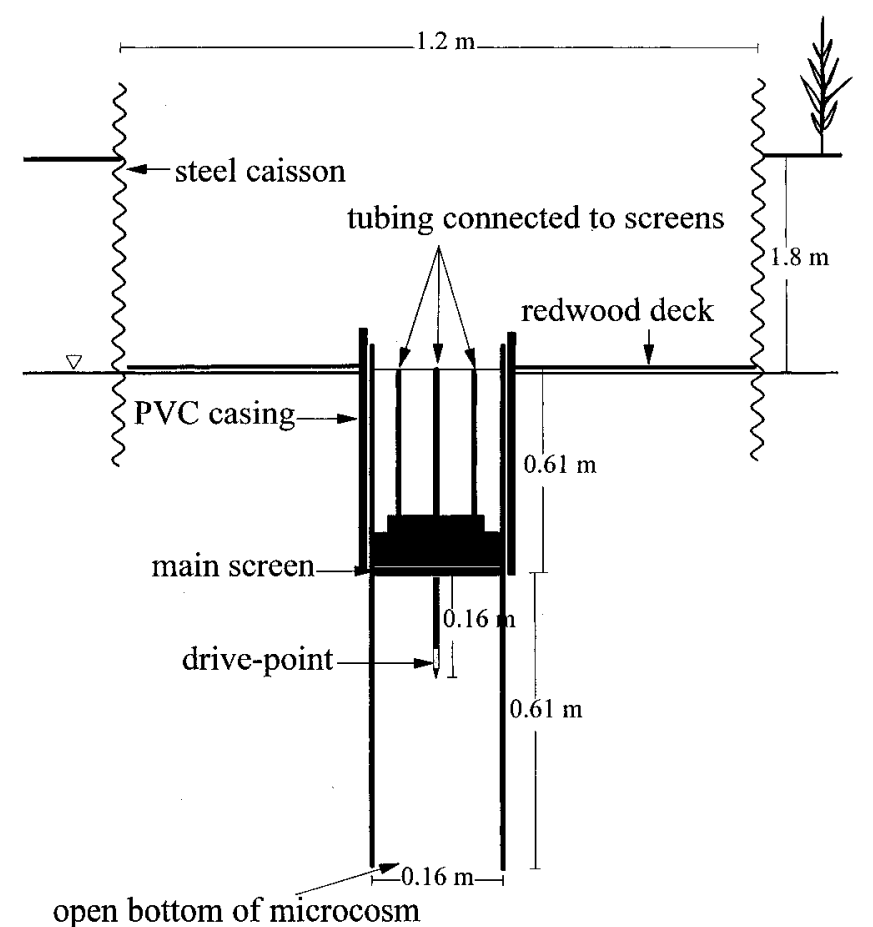

Figure 2. Schematic diagram of ISM.

and mixed by agitation. The resulting injection solution contained $62 \mathrm{mg} / \mathrm{L}$ carbon as ethanol, $50 \mathrm{mg} / \mathrm{L}$ nitrate- $\mathrm{N}, 40$ $\mathrm{mg} / \mathrm{L}$ bromide, and atrazine, DEA, and DIA, each at $20 \mu \mathrm{g} / \mathrm{L}$. The spiked solution was injected under helium pressure, displacing the water within the microcosm.

Samples were collected from the drive-point screen using a 60-mL plastic syringe with a Luer tip. One sample was collected from each microcosm directly following injection; samples were collected every $2-7$ days for 45 days to monitor solute concentrations. The volume of water held stagnant in the tubing $(\sim 10 \mathrm{~mL})$ was removed and discarded prior to sample collection. Samples $(50 \mathrm{~mL})$ for atrazine, DEA, and DIA analysis were transferred from the syringe to $50 \mathrm{~mL}$ precombusted amber glass bottles. Anion samples $(20 \mathrm{~mL})$ were filtered through $0.2 \mu \mathrm{m}$ membrane filters and collected in polyethylene vials. Samples for DOC analysis $(40 \mathrm{~mL})$ were placed in precombusted amber glass vials containing $0.1 \mathrm{mg}$ of $\mathrm{HgCl}_{2}$ as a preservative. Samples were kept on ice during transport to the laboratory. Dissolved oxygen samples $(30 \mathrm{~mL})$ were analyzed immediately after collection.

Sample Analyses. Dissolved oxygen was analyzed in the field using a colorimetric technique calibrated with Winkler titration (Bates and Spalding, 1998). Anions $\left(\mathrm{Cl}^{-}, \mathrm{NO}_{2}^{-}, \mathrm{Br}^{-}\right.$, $\mathrm{NO}_{3}{ }^{-}$, and $\mathrm{SO}_{4}{ }^{-2}$ ) were analyzed by ion chromatography. Dissolved organic carbon was analyzed using an Oceanographic I nternational total organic carbon analyzer calibrated with potassium biphthalate. Since ethanol in the sample would be volatilized in a sequential $C$ determination, total $C$ and total inorganic $C$ were determined separately, with the total organic $C$ determined by difference.

Samples for atrazine, DEA, and DIA analyses were spiked with known amounts of ring-labeled ${ }^{13} \mathrm{C}$ analogues of atrazine, DEA, and DIA. The water samples $(50 \mathrm{~mL})$ were extracted by solid-phase extraction using $\mathrm{C}_{18}$ cartridges containing $1 \mathrm{~g}$ of material. The cartridges were eluted with $2 \mathrm{~mL}$ of ethyl acetate, which was dried with anhydrous sodium sulfate and reduced to $\approx 50 \mu \mathrm{L}$ under a steady stream of dry nitrogen gas. A $1.0 \mu \mathrm{L}$ aliquot was injected onto a gas chromatograph with a mass selective detector. ${ }^{13} \mathrm{C}$ analogues of each compound were used as internal standards, and each compound was analyzed by isotope dilution GC/MS (Cassada et al., 1994). I sotope dilution accounts for differences in extraction efficiency and provides for the quantitation and confirmation of each compound in one analysis (Cassada et al., 1994). Approximate

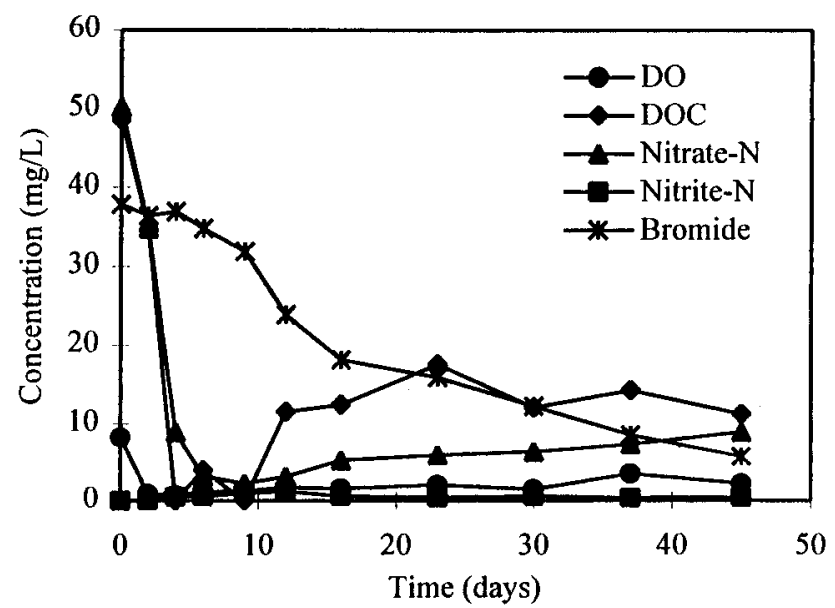

Figure 3. Solute concentrations as a function of time in one amended microcosm (ISM B).

limits of detection for sample analyses were as follows: DO, $0.5 \mathrm{mg} / \mathrm{L}$; anions, $1 \mathrm{mg} / \mathrm{L} ; \mathrm{DOC}, 2 \mathrm{mg} / \mathrm{L}$; atrazine and DEA, $0.4 \mu \mathrm{g} / \mathrm{L} ;$ and DIA, $2 \mu \mathrm{g} / \mathrm{L}$.

Data Analysis. Since the microcosms are open at the bottom, removal of water for sample analysis draws unamended water into the ISM, resulting in dilution of the spiked water and decreasing analyte concentrations. Bromide was included as a nonsorbed, nondegraded tracer to indicate the extent of dilution. Atrazine, DEA, and DIA concentrations were normalized to the initial concentration (measured immediately following the injection into the ISM) and then corrected for dilution using changes in bromide concentration. Sorption of atrazine, DEA, and DIA to similar aquifer materials has been demonstrated to be of very small magnitude (Widmer and Spalding, 1995, 1996). Therefore, degradation of the injected compounds may be indicated by a reduction in normalized concentration with time.

\section{RESULTS AND DISCUSSION}

Denitrification. The DO decreased from background levels of $7-8 \mathrm{mg} / \mathrm{L}$ to $\leq 1 \mathrm{mg} / \mathrm{L}$ within 4 days. The DO remained $\$ 3 \mathrm{mg} / \mathrm{L}$ for the duration of the experiment (Figure 3). After the oxygen was depleted, nitrate-N concentrations decreased from $\approx 50$ to $\lesssim 2$ $\mathrm{mg} / \mathrm{L}$ within 9 days, followed by a slow increase in nitrate concentrations as water from the aquifer was drawn into the microcosms (Figure 3). Nitrite-N concentrations did not exceed $3 \mathrm{mg} / \mathrm{L}$ at any time in the experiment (Figure 3). The DOC decreased from the injected concentration to $<10 \mathrm{mg} / \mathrm{L}$ within 6 days, followed by increasing DOC levels (Figure 3) when microbial proliferation and cell death increased soluble C.

The results observed in this study are similar to but somewhat slower than those reported by Bates and Spalding (1998). Repeated measurements of induced denitrification at this site indicated that from 40 to $~ 92$ $\mathrm{h}$ was required to deplete $50 \mathrm{mg} / \mathrm{L}$ nitrate $\mathrm{N}$ and the nitrite formed during the denitrification reaction (Bates and Spalding, 1998). Denitrification experiments using $50 \mathrm{mg}$ of $\mathrm{C} / \mathrm{L}$ as ethanol showed complete removal of 50 $\mathrm{mg} / \mathrm{L} \mathrm{NO}_{3}-\mathrm{N}$ in $40 \mathrm{~h}$. Denitrification rates slowed with the addition of higher concentrations of organic carbon. The denitrification rates observed in this experiment may be slower than those reported for other studies at this site (Bates and Spalding, 1998) because of temporal and spatial heterogeneity in environmental conditions, such as temperature, $\mathrm{Eh}, \mathrm{pH}$, and microbial population.

Temperature, in particular, may have been a factor in determining denitrification rates at this site. Tem- 


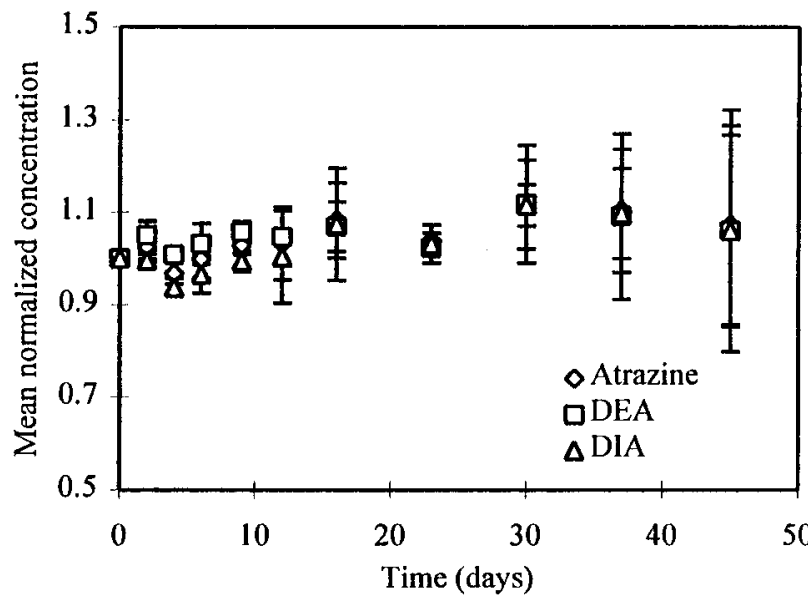

Figure 4. Persistence of atrazine, DEA, and DIA under low$\mathrm{O}_{2}$ conditions. Values are means of two duplicate microcosms; error bars indicate variability between the two microcosms and not the uncertainty in chemical measurement.

perature has been reported to affect the rate of denitrification in soils, with the maximum denitrification rate observed at $25^{\circ} \mathrm{C}$, and a decreasing rate with decreasing temperature ( $\mathrm{Lal}, 1988$ ). The temperature of the shallow groundwater was likely higher in the denitrification studies reported in Bates and Spalding (1998), which were conducted in the summer and early autumn, than the temperature in this study, conducted in mid to late autumn. Average groundwater temperatures in the Central Platte region of Nebraska have been reported by Spalding and Exner (1980). Temperatures at depths similar to those of the installed ISMs were about $11 \pm 3.5^{\circ} \mathrm{C}$, with winter shallow groundwater temperatures as much as $10^{\circ} \mathrm{C}$ lower than those measured in the summer (Spalding and Exner, 1980). Since no temperature measurements were made in either study, the effect of temperature on denitrification rate cannot be further examined here.

The atrazine concentrations used in this study should not have affected the rate of denitrification. Bradley et al. (1994) found that the presence of relatively high concentrations of atrazine $(\sim 100 \mu \mathrm{g} / \mathrm{L})$ did not alter denitrification rates in laboratory microcosms of aquifer sediments amended with glucose.

Persistence of Injected Triazines. Atrazine, DEA, and DIA concentrations normal ized to the conservative tracer concentration did not show a significant decrease with time $(\alpha=0.10)$ (Figure 4$)$. These results indicate that these compounds are relatively stable under the low-oxygen conditions induced in this aquifer. Degradation of atrazine in the presence of additional sources of carbon and energy has been demonstrated in laboratory mi crocosms (Mandel baum et al., 1995; Radosevich et al., 1995; Wolf and Martin, 1975). Degradation in soils spiked with atrazine and inoculated with atrazinedegrading bacteria has been documented (YanzeKontchou and Gschwind, 1995; Radosevich et al., 1997)

The change in concentration of atrazine and its metabolites may be attributed to dilution of the amended water (injected into the ISM) with aquifer water drawn in through the open bottom of the ISM. Considering the ISM to be a cell containing $3.7 \mathrm{~L}$ of pore water, the dilution of the amended water may be approximated by assuming the same volume of water is drawn in through the bottom as was withdrawn with each sampling, with perfect mixing of the water within the ISM. This gives a "predicted" concentration based only on dilution.

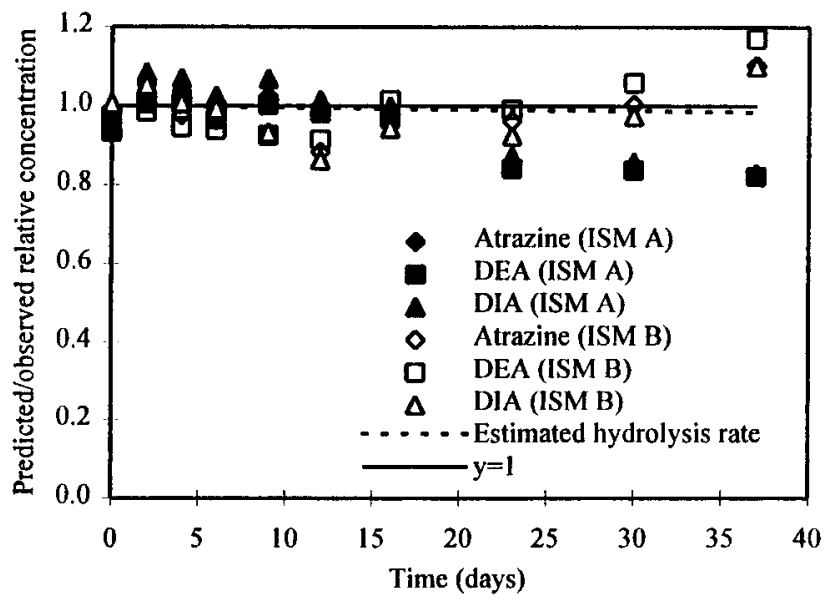

Figure 5. Effect of dilution on changing chemical concentrations in duplicate ISMs. Predicted concentrations are based on removal of mass with sampling and replacement of withdrawn water with aquifer water drawn in through the open bottom of the ISM. Both predicted and observed concentrations are normalized to bromide concentrations. The estimated hydrolysis rate is taken as a $3 \%$ decrease in 70 days (Wehtje et al., 1983).

These predicted results (normalized to the bromide concentration) may be compared to the concentration changes observed in the ISMs to assess the impact of dilution on relative concentrations in the ISMs (Figure 5).

Because the aquifer water contains the triazine compounds included in this study at nonzero levels, while bromide is not detected in background samples, dilution of amended water with aquifer water will increase the relative concentration of triazine/bromide (Figure 4). When stepwise dilution is considered (Figure 5), predicted/observed relative concentrations decrease significantly with time $(\alpha=0.01)$ for one replicate microcosm (ISM A) but show no correlation with time for the other microcosm (ISM B). For both microcosms, the mean of the predicted/observed normalized concentrations was not significantly different from 1 ( $\alpha=0.05$ ) except for DEA in ISM $A$, for which the mean was significantly less than 1.

Background samples collected from a third ISM before the experiment was initiated showed atrazine present at $0.55 \mathrm{mg} / \mathrm{L}$, DEA at $0.99 \mathrm{mg} / \mathrm{L}$, and DI A at $0.13 \mathrm{mg} / \mathrm{L}$. These concentrations were used to calculate the pre dicted concentrations for both ISMs in Figure 5. The composition of the shallow groundwater outside the ISMs was not monitored during the experiment. However, very small changes (submicrograms per liter) in shallow groundwater concentrations have been observed in this area during the autumn and winter seasons in the absence of local recharge (R. F. Spalding, unpublished data). Meteorological records indicate minimal precipitation throughout this study, totaling $\sim 2.7 \mathrm{~cm}$, with a maximum daily rainfall of $0.7 \mathrm{~cm}$. It is therefore unlikely that large fluctuations in the concentration of atrazine and its metabolites occurred during the experiment. In addition, since only a small amount of water was withdrawn from the ISMs with each sampling, predicted/observed relative concentrations are relatively insensitive to concentration changes in the aquifer water. Maximum changes in predicted/observed relative concentrations shown in Figure 5 that would result from a 5-fold increase in aquifer concentration of each compound would be $\leqslant 5 \%$ for atrazine, $<9 \%$ for DEA, and $\leqslant 1 \%$ for DIA. 
The variability between the two replicate microcosms may reflect the spatial and temporal heterogeneity of conditions. These may include, but are not limited to, the microbial population, the hydrogeol ogical conditions that affect the composition of water available for exchange with theISMs, and the dynamics of exchange, which is likely more complex than the simple dilution considered here.

It has been proposed that the abiotic hydrolysis of atrazine may be the dominant degradative process occurring in groundwater (Wehtje et al., 1983). The rate of atrazine hydrolysis in aerobic groundwater has been estimated as producing a $3 \%$ decrease in atrazine concentration in 70 days (Wehtje et al., 1983). The decrease in relative concentration that would result from a decrease of this magnitude in the ISMS is indicated in Figure 5. Decreases in concentration of this order are too small to be detected in this study, on the basis of the observed variability within and between ISMS (Figure 5).

Atrazine contamination of the groundwater in this area is extensive (Spalding et al., 1989; University of Nebraska Water Sciences Laboratory, 1994); the microbial population has been exposed to these compounds for many years. The time required to partially degrade atrazine in anaerobic laboratory microcosms ranges from a few days [e.g., J essee et al. (1983), Radosevich et al. (1995), and Stucki et al. (1995)] to months or more (Nair and Schnoor, 1992). In this study, low- $\mathrm{O}_{2}$ conditions could be sustained for only 45 days. It is unknown whether this is sufficient time for the microbial population to acdimate to these conditions. The lack of degradation could be due to unfavorable conditions or the absence of a microbial population capable of degrading atrazine under anaerobic conditions. Atrazine mineralization rates in surface soils have been shown to be reduced by the presence of high concentrations of $\mathrm{NO}_{3}$ (2.5 mg of $\mathrm{NO}_{3}-\mathrm{N} / \mathrm{g}$ of soil) (Alvey and Crowley, 1995); the highest $\mathrm{NO}_{3}-\mathrm{N}$ concentrations used in this study were $\approx 2$ orders of magnitude lower than those showing an effect in Alvey and Crowley (1995) and were estimated as $0.01 \mathrm{mg}$ of $\mathrm{NO}_{3}-\mathrm{N} / \mathrm{g}$ of sediment. The rate of naphthalene degradation under denitrifying conditions in surface soils was not affected by the nitrate concentration in a study by Mihelcic and Luthy (1991), with $\mathrm{NO}_{3}$ concentrations of $8-30 \mathrm{mg}$ of $\mathrm{NO}_{3}-\mathrm{N} / \mathrm{L}$.

Although removal of one alkyl group has been proposed as a rate-limiting step in further transformation of atrazine (Behki and Khan, 1986; Wolf and Martin, 1975), the degradation of atrazine's dealkylated metabolites (DEA and DIA) was no different from that of the parent compound. Transformation pathways proposed for surface soils need not be consistent with those occurring in aquifers, due to differing environmental conditions and microbial populations. While there appears to be some evidence for degradation of atrazine and its monodealkylated metabolites in one amended microcosm, these results were not observed in a replicate microcosm (Figure 5). The results of the present study, taken in conjunction with those of a previously conducted field study in an aerobic aquifer (Widmer and Spalding, 1995), indicate that atrazine, DEA, and DIA are relatively persistent in groundwater over periods of several months, regardless of oxidizing conditions. These results support the observation of steady-state concentrations of atrazine, DEA, and DIA in groundwater in this area contaminated by long-term atrazine use (University of Nebraska Water Sciences Laboratory, 1994; R. F. Spalding, 1995, unpublished data).

\section{ABBREVIATIONS USED}

DEA, deethylatrazine; DI A, dei sopropylatrazine; DO, dissolved oxygen; ISM, in situ microcosm; DOC, dissolved organic carbon.

\section{ACKNOWLEDGMENT}

This research was completed while the principal author was a graduate student at the University of Nebraska. Herbert K. Bates assisted with the injection of solutes and sample collection. We appreciate the cooperation of J ohn J efferson in providing a field site. Patrick Shea, Stephen Comfort, J ianying Gan, Scott Yates, and two anonymous reviewers provided hel pful comments on the manuscript.

\section{LITERATURE CITED}

Agertved, J .; Rügge, K.; Barker, J . F. Transformation of the herbicides MCPP and atrazine under natural aquifer conditions. Ground Water 1992, 30, 500-506.

Alvey, S.; Crowley, D. E. Influence of organic amendments on biodegradation of atrazine as a nitrogen source. J . Environ. Qual. 1995, 24, 1156-1162.

Assaf, N. A.; Turco, R. F. Influence of carbon and nitrogen application on the mineralization of atrazine and its metabolites in soil. Pestic. Sci. 1994, 41, 41-47.

Bates, H. K.; Spalding, R. F. Aquifer denitrification as interpreted from in situ microcosm experiments. J . Environ. Qual. 1998, in press.

Behki, R. M.; Khan, S. U. Degradation of atrazine by Pseudomonas: $\mathrm{N}$-dealkylation and dehalogenation of atrazine and its metabolites. J. Agric. Food Chem. 1986, 34, 746-749.

Bradley, P. M.; Chapelle, F. H.; J agucki, M. L.; McMahon, P. B. Effect of atrazine on potential denitrification in aquifer sediments. Soil Biol. Biochem. 1994, 26, 523-524.

Cassada, D. A.; Spalding, R. F.; Cai, Z.; Gross, M. L. Determination of atrazine, deethylatrazine, and deisopropylatrazine in water and sediment by isotope dilution gas chromatography-mass spectrometry. Anal. Chim. Acta 1994, 287, 7-15.

Chung, K. H.; Ro, K. S.; Roy, D. Atrazine biotransformation in wetland sediment under different nutrient conditions-I: Anaerobic. J. Environ. Sci. Health, Part A 1995, 30, 109-120.

Chung, K. H.; Ro, K. S.; Roy, D. Fate and enhancement of atrazine biotransformation in anaerobic wetland sediment. Water Res. 1996, 30, 341-346.

Giardina, M. C.; Giardi, M. T.; Filacchioni, G. 4-Amino-2chloro-1,3,5-triazine: A new metabolite of atrazine by a soil bacterium. Agric. Biol. Chem. 1980, 44, 2067-2072.

Giardina, M. C.; Giardi, M. T.; Filacchioni, G. Atrazine metabolism by Nocardia: Elucidation of initial pathway and synthesis of potential intermediates. Agric. Biol. Chem. 1982, 46, 1439-1445.

Gibson, S. A.; Suflita, J . M. Anaerobic biodegradation of 2,4,5trichlorophenoxyacetic acid in samples from a methanogenic aquifer: Stimulation by short-chain organic acids and alcohols. Appl. Environ. Microbiol. 1990, 56, 1825-1832.

Gillham, R. W.; Starr, R. C.; Miller, D. J . A device for in situ determination of geochemical transport parameters, 2. Biochemical reactions. Ground Water 1990, 28, 858-862.

Gu, J . D.; Berry, D. F.; Taraban, R. H.; Martens, D. S.; Walker, H. L., J r.; Edmonds, W. J. Biodegradability of Atrazine, Cyanazine, and Dicamba in Wetland Soils; VPI-WWRRC Bulletin 172; Virginia Water Resources Research Center and Virginia Polytechnic Institute and State University: Blacksburg, VA, 1992. 
J essee, J . A.; Benoit, R. E.; Hendricks, A. C.; Allen, G. C.; Neal, J . L. Anaerobic degradation of cyanuric acid, cysteine, and atrazine by a facultative anaerobic bacterium. Appl. Environ. Microbiol. 1983, 45, 97-102.

J ones, T. W.; Kemp, W. M.; Stevenson, J. C.; Means, J. C. Degradation of atrazine in estuarine water/sediment systems and soils. J . Environ. Qual. 1982, 11, 632-638.

Kolpin, D. W.; Thurman, E. M.; Goolsby, D. A. Occurrence of selected pesticides and their metabolites in near-surface aquifers of the midwestern United States. Environ. Sci. Technol. 1996, 30, 335-340.

Kruger, E. L.; Rice, P.J .; Anhalt, J . C.; Anderson, T. A.; Coats, J . R. Comparative fates of atrazine and deethylatrazine in sterile and nonsterile soils. J . Environ. Qual. 1997, 26, 95101.

Lal, R. Nature and habitats of microbes of nitrogen cycle. In Pesticides and Nitrogen Cycle; Lal, R., Lal, S., Eds.; CRC Press: Boca Raton, FL, 1988.

Mandel baum, R. T.; Wackett, L. P.; Allan, D. L. Mineralization of the s-triazine ring of atrazine by stable bacterial mixed cultures. Appl. Environ. Microbiol. 1993, 59, 1695-1701.

Mandelbaum, R. T.; Allan, D. L.; Wackett, L. P. I solation and characterization of a Pseudomonas sp. that mineralizes the s-triazine herbicide atrazine. Appl. Environ. Microbiol. 1995, 61, 1451-1457.

McMahon, P. B.; Chapelle, F. H.; J agucki, M. L. Atrazine mineralization of alluvial-aquifer sediments under aerobic conditions. Environ. Sci. Technol. 1992, 26, 1556-1559.

Mihelcic, J . R.; Luthy, R. G. Sorption and microbial degradation of naphthalene in soil-water suspensions under denitrification conditions. Environ. Sci. Technol . 1991, 25, 169177.

Mirgain, I.; Green, G. A.; Monteil, H. Degradation of atrazine in laboratory microcosms: I solation and identification of the biodegrading bacteria. Environ. Toxicol. Chem. 1993, 12 1627-1634.

Nair, D. R.; Schnoor, J . L. Effect of two el ectron acceptors on atrazine mineralization rates in soil. Environ. Sci. Technol. 1992, 26, 2298-2300.

Nair, D. R.; Schnoor, J . L. Effect of soil conditions on model parameters and atrazine mineralization rates. Water Res. 1994, 28, 1199-1205.

Radosevich, M.; Traina, S. J .; Hao, Y.-L.; Tuovinen, O. H. Degradation and mineralization of atrazine by a soil bacte rial isolate. Appl. Environ. Microbiol. 1995, 61, 297-302.

Radosevich, M.; Traina, S. J .; Tuovinen, O. H. Atrazine mineralization in laboratory-aged soil microcosms inoculated with s-triazine-degrading bacteria. J . Environ. Qual. 1997, 26, 206-214.

Ritter, W. F. Pesticide contamination of ground water in the United States - A review. J. Environ. Sci. Health, Part B 1990, 25, 1-25

Ro, K. S.; Chung, K. H. Atrazine biotransformation in wetland sediment under different nutrient conditions-II: Aerobic. J . Environ. Sci. Health, Part A 1995, 30, 121-131.
Spalding, R. F.; Exner, M. E. Areal, vertical, and temporal differences in ground water chemistry: I. Inorganic constituents. J . Environ. Qual. 1980, 9, 466-479.

Spalding, R. F.; Exner, M. E.; Sullivan, J . J .; Lyon, P. A. Chemical seepage from a tail water recovery pit to adjacent ground water. J. Environ. Qual. 1979, 8, 374-383.

Spalding, R. F.; Burbach, M. E.; Exner, M. E. Pesticides in Nebraska's ground water. Ground Water Monit. Rev. 1989 9, 126-133.

Stucki, G.; Yu, C. W.; Baumgartner, T.; Gonzalez-Valero, J. F. Microbial atrazine mineralisation under carbon limited and denitrifying conditions. Water Res. 1995, 29, 291-296.

University of Nebraska Water Sciences Laboratory. Assessment of Pesticide Occurrence in Nebraska Ground Water; University of Nebraska Water Sciences Laboratory, Water Center/Environmental Programs: Lincoln, NE, 1994.

Vanderheyden, V.; Debongnie, P.; Pussemier, L. Accelerated degradation and mineralization of atrazine in surface and subsurface soil materials. Pestic. Sci. 1997, 49, 237-242.

Wehtje, G. R.; Spalding, R. F.; Burnside, O. C.; Lowry, S. R.; Leavitt, J . R. C. Biological significance of atrazine under aquifer conditions. Weed Sci. 1983, 31, 610-618.

Widmer, S. K.; Spalding, R. F. A natural gradient transport study of selected herbicides. J. Environ. Qual. 1995, 24, 445-453.

Widmer, S. K.; Spalding, R. F. Assessment of herbicide transport and persistence in groundwater: a review. In Herbicide Metabolites in Surface Water and Groundwater; Meyer, M. T., Thurman, E. M., Eds.; ACS Symposium Series 630; American Chemical Society: Washington, DC, 1996; pp 271-287.

Wilber, G. G.; Parkin, G. F. Kinetics of alachlor and atrazine biotransformation under various electron acceptor conditions. Environ. Toxicol. Chem. 1995, 14, 237-244.

Wolf, D. C.; Martin, J . P. Microbial decomposition of ring- ${ }^{14} \mathrm{C}$ atrazine, cyanuric acid, and 2-chloro-4,6-diamino-s-triazine. J . Environ. Qual. 1975, 4, 134-139.

Yanze-Kontchou, C.; Gschwind, N. Mineralization of the herbicide atrazine as a carbon source by a Pseudomonas strain. Appl. Environ. Microbiol. 1994, 60, 4297-4302.

Yanze-Kontchou, C.; Gschwind, N. Mineralization of the herbicide atrazine in soil inoculated with a Pseudomonas strain. J . Agric. Food Chem. 1995, 43, 2291-2294.

Received for review J uly 21, 1997. Revised manuscript received November 20, 1997. Accepted November 23, 1997. This research was funded through the U.S. Bureau of Reclamation, the Nebraska Research Initiative, and a fellowship from the University of Nebraska Medical Center's Environmental Toxicology and Carcinogenesis Graduate Program.

J F 9706235 